\title{
Chinese Experiential-Based Conceptual Metaphors in Terms of Thread*
}

\author{
Yujie Su ${ }^{1,2}$ \\ ${ }^{1}$ Wenzhou University, Wenzhou, China \\ ${ }^{2}$ Chonnam National University, Gwangju, Korea \\ Email: 424185224@qq.com
}

How to cite this paper: Su, Y.J. (2017) Chinese Experiential-Based Conceptual Metaphors in Terms of Thread. Open Access Library Journal, 4: e3749. https://doi.org/10.4236/oalib.1103749

Received: June 20, 2017

Accepted: August 20, 2017

Published: August 23, 2017

Copyright (c) 2017 by author and Open Access Library Inc.

This work is licensed under the Creative Commons Attribution International License (CC BY 4.0).

http://creativecommons.org/licenses/by/4.0/

\begin{abstract}
Textile production played a significant role in Ancient China and the related expressions entered into the scope of daily life. The present research intends to study the conceptual metaphors involving thread or string in Chinese and sheds some light on Chinese cognition of guān-xì (关系 relation) or lián-xi (联系 link). On the basis of data collected from Center for Chinese Linguistics (CCL) and Modern Chinese Dictionary, an investigation of experiential-based conceptual metaphors of thread is made, in terms of the prototypicality and image schema of LINK.
\end{abstract}

\section{Subject Areas}

Education, Linguistics

\section{Keywords}

Experiential-Based, Conceptual Metaphor, Prototypicality, Image Schema

\section{Introduction}

Ancient China relied heavily on farming and textile production. There are many words and expressions related to textile production entering into life domain and keeping influencing our life as well as our cognition of the world around us. People are social groups, involved in this and that relation in the real world. In modern

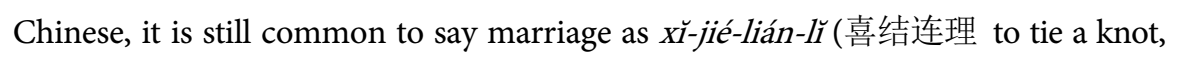
to marry), ambition in life as biān-zhi-lí-xiăng (编织理想 to weave dreams), a big crowd as rén-qún-rú-zhī (人群如织 a crowd as weaved together). What's more, new friends are to be made as jié-jiāo (结交 to make) new friends, and one is very ^I would like to express my appreciation to Professor Cho Yongsun for her comments and suggestions. 
likely to be tied down or qiän-bàn (牵绊 to tie down) by his or her family.

Language is the carrier of a culture, reflecting certain shared cognition. Palmer and Sherifian [1] argued that language was both a cultural activity and an instrument for organizing other cultural domain, and culture structured the interpretation of language. Sharifian [2] referred to the relationship between language and culture as a two-fold one, and stated that language and culture both communicated cultural conceptualizations and meanwhile embodied them. That is, lexical items are understood on the basis of how speakers of a language categorize their experiences, and on the other hand, lexical items are also representations or labels for schemas that are largely culturally constructed. Yu [3] [4] put forward a "circular triangle relationship", based on his studies of Chinese and comparison between English and Chinese, as shown in Figure 1.

$\mathrm{Yu}$ intended to claim that the language form originates from an embodied experience and represents a certain culture, a certain shared cognition. Lakoff and Johnson [5] have found that metaphor prevails in everyday life, both in language and in thought and action. They believe that the essence of metaphor is understanding and experiencing one kind of thing in terms of another.

In the long history of textile industry, lots of expressions involving thread or string were created and put into repeated use, then became well-used metaphorical patterns and widely accepted by Chinese people. In the meantime, these expressions affect the people's thought and action, entrenching the Chinese cognition of the surrounding world.

At first, a survey into the textile language in Chinese in the Chinese corpus developed by Beijing University (Center for Chinese Corpus, CCL) [6] is done to gain a general view that there is a rich storage of textile language in Chinese. Then it introduces a cognitive study of the textile language in terms of the image schema of LINK. The third part presents discussion on the ground of textile language in Chinese and the LINK image Schema.

\section{A Survey of Textile Expressions in Chinese}

In order to gain a comparatively general view of the textile language in Chinese, a survey of textile expressions is done in the exploration into the Modern Chinese Dictionary [7].

Chinese characters are well-known for the complicated writing system, for it is not alphabetically based. A Chinese character contains both an indication of pronunciation and an indication of meaning. And a Chinese character is usually

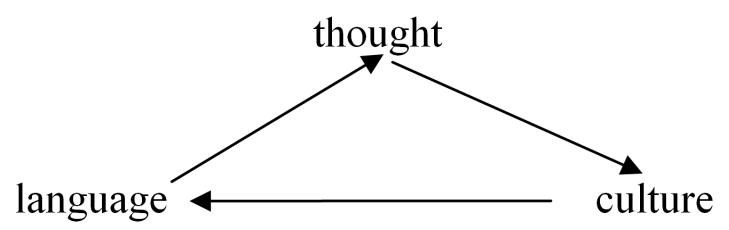

Figure 1. The "triangled-constraint" relationship between language, thought and culture. 
an ideogram, expressing meaning ironically. Almost all of the textile languages are characters of ideograms, taking “年” (meaning silk, sī 丝) as radicals [8].

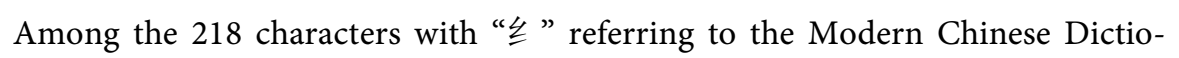
nary, those related with LINK and also prevail in modern Chinese are jing (经 warp), wéi (纬 weft), xiàn (线 thread or string), shéng (绳 rope), sī (丝 silk), chán (缠 twine or tangle), wán (绾 tie or coil up), fü (缚 bind), băng (绑 bind), ji (系 bind), jié(结 tie or wind), rào (绕 roll), biān (编 weave), and $z h \bar{i}$ (织 weave). xiàn (线 thread or string), shéng (绳 rope), and sī (丝 silk)refer to the materials used in the textile production, the others like chán (缠 twine or tangle), wán (绾 tie or coil up), fù (缚 bind), băng (绑 bind), jì (系 bind), jié (结 wind), rào (绕 roll), biān (编 weave), and zhī (织 weave) are actions often applied in the production. All the actions mentioned here refer to the combination of two things together. And the opposite actions should also be considered in the present research.

Table 1 demonstrates that the word jié (结 tie or wind) is synonymous to chán (缠 twine or tangle), wán (绾 tie or coil up), fü (缚 bind), băng (绑 bind), ji (系 bind), jié(结 tie or wind), rào (绕 roll), biān (编 weave), and $z h \bar{i}$ (织 weave). And it can be seen as the prototypical term for other verbs. Thus, for a further understanding of metaphorical use of textile expressions, jié (结 tie or wind) and its antonym jiě (解 unwind or untie) are regarded as the center for the present study.

\section{The Image Schema of LINK}

In Chinese, textile production is called “jīng-tiān-wéi-di (经天纬地 warp as the sky and weft as the earth: an ability to rule the country)" [9]. Weft and warp are two threads involved in textile production. Weft is built one after another by weaving the thread in and out between the warp threads, crossing each one as it

Table 1. Definition, synonyms and antonyms of verbs in textile production.

\begin{tabular}{|c|c|c|c|}
\hline verbs & definition & synonyms & antonyms \\
\hline chán (缠 wind or tangle), & 缠绕(chán-rào wind) & rào (绕 roll); jié(结 tie or wind) & jiě (解 unwind or untie) \\
\hline wán (绾 tie or coil up), & $\begin{array}{c}\text { 把长条形的东西盘绕起来打成结(tie } \\
\text { things with long strips) }\end{array}$ & jié(结 tie or wind) & jiě (解 unwind or untie) \\
\hline fü (缚 bind) & 捆绑（tie up） & jié(结 tie or wind) & jiě (解 unwind or untie) \\
\hline băng (绑 bind) & $\begin{array}{c}\text { 用绳、带等缠绕或捆扎 } \\
\text { (tie or wind with rope or string) }\end{array}$ & jié(结 tie or wind) & jiě (解 unwind or untie) \\
\hline$j i$ (系 bind), & 打结 (tie) & $j i e ́($ 结 tie or wind) & jiè (解 unwind or untie) \\
\hline jié(结 tie or wind) & $\begin{array}{c}\text { 用线、绳、草等条状物打结或编织 } \\
\text { (tie or weave with tenuous } \\
\text { things like thread, rope, straw, etc.) }\end{array}$ & $\begin{array}{c}\text { chán (缠 twine or tangle), wán (绾 tie or coil up), fü } \\
\text { (缚 bind), băng (绑 bind), } j i \text { (系 bind), rào (绕 roll), } \\
\text { biän (编 weave), and } z h \bar{i} \text { (织 weave) }\end{array}$ & jiě (解 unwind or untie) \\
\hline rào (绕 roll) & 细绕 $($ wind $)$ & jié(结 tie or wind) & jiè (解 unwind or untie) \\
\hline biān (编 weave) & $\begin{array}{c}\text { 把细长条状的东西交叉组织起来 } \\
\text { (cross tenuous things together) }\end{array}$ & jié(结 tie or wind) & jiě (解 unwind or untie) \\
\hline$z h \bar{h}$ (织 weave) & $\begin{array}{c}\text { 使纱或线交叉穿过，制成绸、布、呢子 } \\
\text { 等 (cross yarn or thread together into } \\
\text { pieces of silk, cloth or wool, etc.) }\end{array}$ & jié(结 tie or wind) & jiě (解 unwind or untie) \\
\hline
\end{tabular}


passes by. A thread or string has a starting point and an ending point, like a line segment. The same thread can be cut in the middle or knotted at the ending point, while different threads can be tied together and as well the tie or knot can be untied. What's more, threads crossing over in order is weaving while threads crossing over in disorder is tangling or intertwining.

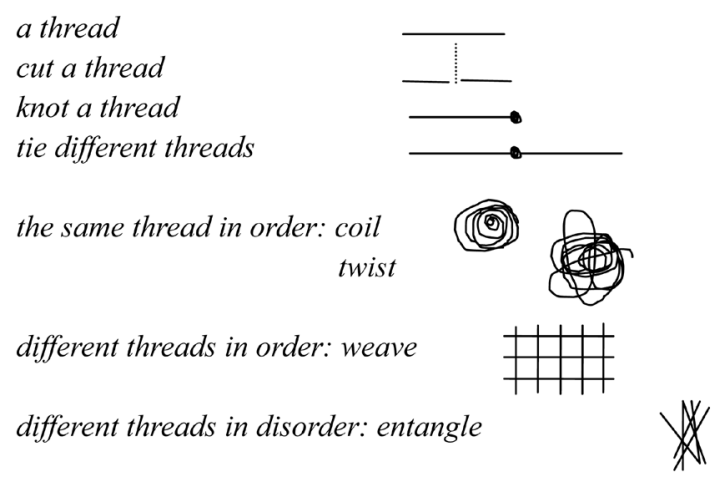

The thread or string in the weaving process connects or establish a certain link between objects. Then the engagement and disengagement of link is extended to different objects. According to the definition obtained via Google search engine, a link schema is defined as an image schema that consists of two or more entities, connected physically or metaphorically, and the bond between them.

(1) an image schema of LINK consisting of two entities

two entities establish a link:

two entities are cut off the link:

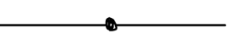

For example, in the sentence “解铃还需系铃人 (Whoever started the trouble should end it)”, “系 (tie, knot)” and “解 (untie, unknot)” are opposite actions. A link between two entities is established by tying the bell, while the link is cut off by untying the bell. And in the end of a love story it is always happy to see that the lovers get united in a marriage, in Chinese “喜结姻缘 (to get married)”. Here “结” literally means knit or knot, and the marriage is believed to be destined as “姻缘”. In Chinese the famous saying “千里姻缘一线牵 (a fate match across a thousand miles is drawn by a thread)" indicates that a man and a woman is linked by a fate thread.

(2) an image schema of LINK consisting of more than two entities

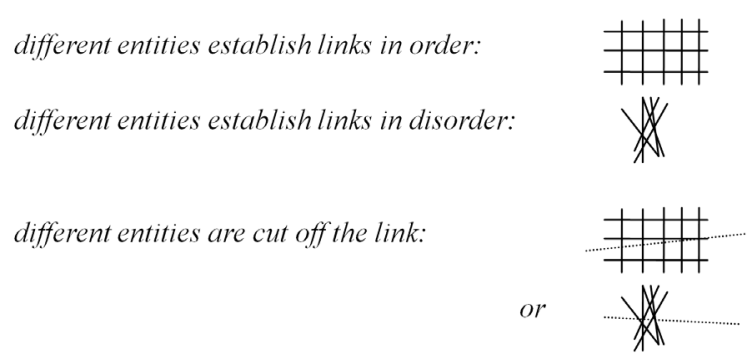


For example, in the sentence “她深陷情郎编织的情网无法自拔 (She lost herself in the love net her lover had woven and couldn't escape it.)”, “编织 (weave, knit)" is usually a textile expression which is defined in the Longman Dictionary of Contemporary English [10]: to make cloth, a carpet, a basket etc. by crossing threads or thin pieces under and over each other by hand or on a loom. Here the love net is metaphorical conceptualized as a net woven by the lover's words, facial expressions, acts, and so on. In the sentence “交流会人车交 织 (at the fair flows of population and traffic are intertwined.)”, “交织 (interweave, intertwine)" entails the image of a vast crowd and a heavy traffic at the fair, each flow like a thread weaving or interweaving without an order. And the opposites to “编织” or “交织” are usually “解开 (untie)", “拆开 (unpack)” or “分开 (separate)", etc.

In essence, thread or string metaphors have prototypical experiential basis in people's textile production. In ancient time weaving was an essential part of life, thus many weaving concepts were mapped metaphorically onto the concept of life. The art of weaving is fundamental for the understanding of the world we are living in. In ancient times, due to low technology, textile production is closely related with women's work, such as weaving, knitting, spinning, embroidering, and so on. In the case of the conceptual metaphors involving thread or string in Chinese, they are embodied or experiential-based in textile production.

\section{Metaphorical Use of Textile-Related Expressions for LINK}

Textile production has a long history in China or in the human history. In the textile production, the thread or string plays an important role, for a thread can be weaved or knitted into a textile product. Many textile-related expressions, such as jīng-wéi (经纬 warp and weft), jié (结 a knot, knotting or binding) or jiě (解 releasing or undbinding), yí-xiàn (一线 a thread of) and $y \bar{i}-s \bar{i}$ (一丝 a thread of ), etc., enter the life domain.

\subsection{From 经纬 (jīng-wéi) to 关系(guānxi)}

The expression containing warp and weft in Chinese is jingwéi, which have multiple meanings, as shown in Table 2:

Table 2. Definitions of jīng-wéi.

经纬 jīngwéi

1) 织物的直线叫经, 横线叫纬 the vertical thread in the textile is called warp and the horizontal one is weft

2) 道路, 南北为经, 东西为纬 road, the road running from north to south called warp and the road running from west to east weft

3) 常道 constant Dao

4) 治理 governance or management

5) 经书和纬书 jingshu and weishu

6) 经纬度 longitude and latitude

《现代汉语词典》 Modern Chinese Dictionary 
The first sense is literal meaning for warp and weft. The second sense ranks the first in the prototypicality, for the roads are compared to be threads in the textile. The road runs from north to south, regarded as vertical in terms of geography, while the road runs from west to east as horizontal. Similarly, the rivers resemble roads, running vertically and horizontally. By searching the Chinese corpus developed by Beijing University, 2649 items of jīngwéi used literally and metaphorically are retrieved. The fourth sense ranks the first, altogether 1746 items, followed by the sixth sense 149 items and the second sense 41 items.

Comparing with jīng-wéi, niŭ-dài (纽带) is more abstract and more distant from the original connecting image of warp and weft, but keeping the image of LINK, binding with thread-like things. By searching the Chinese corpus developed by Beijing University, 3444 items of niŭ-dài used literally and metaphorically are retrieved.

By scanning the examples in the corpus, niŭ-dài can be entities concrete or abstract like family, organization, money, culture, emotion, social system, relation, etc.

The most metaphorical one is 关系 guān-xi. Comparing with jīng-wéi and niŭ-dài, guān-xì is even more abstract and conceptual. It means the state of mutual interaction and influence between entities or the association of certain kind between humans or objects.

In reality people come into contact with each other in all kinds of relations, like family relations (jiā-tíng-guān-xi 家庭关系), social relations (shè-hui$g u a \bar{n}-x i$ 社会关系), interpersonal relations (rén-ji-guān-xi 人际关系), and so on. And there are also national relations (guó-jiā-guān-xi 国家关系) and international relations (guó-jì-guān-xi 国际关系), economical relations (jīng-jì-guān-xi 经济关系), political relations (zhèng-zhi-guān-xi 政治关系), cultural relations (wén-huà-guān-xì 文化关系), and so on. Nothing in the world can stand alone without involving into a certain relation of some kind.

\section{2. jié (结 a Knot, Knotting or Binding) or jiě (解 Releasing or Undbinding)}

A famous Chinese saying goes like “yuān-jiā-yí-jiě-bù-yí-jié (冤家宜解不宜结: an enemy is better to unbind than bind)” or “yuān-chóu-yí-jiè-bù-yí-jié (冤仇宜 解不宜结: enmity is better to unbind than bind)", which means that it's better to make friends than make enemies. The two jié (knot, knotting or binding) or jiě (releasing or unbinding) are opposite actions when doing with the thread.

\subsection{1. jié (结 a Knot; Knotting or Binding)}

The Chinese word jié (结), if used as a noun refers to a knot formed by tying two threads, such as dă-jié (打结, to knot or tie), sü-jié (死结, dead knot: a fastened knot), xīn-jié (心结, heart knot: a scar), zhèng-jié(症结, symptom knot: crux or crucial reasons). It is more common to use jié (结) as a verb in Chinese, such as jié-jiāo (结交, to make friends), jié-shí(结识, to get to know somebody), jiéchóu (结仇, to become enemies), jié-wèi-fū-qī (结为夫妻) or jié-wèi-fü-fü (结为夫妇) 
or jié-lián-lı̆ (结连理, to marry), jié-shù (结束, to end), di-jié (缔结, to cooperate), lián-jié (联结, to unite) and so on.

By looking into the Modern Chinese Dictionary there are 28 verb entries of jié. And in practical usage all of these verb entries have nominal usage. And by closely looking at the construction pattern, it is also found that the entities that are combined with jié vary in degree of concreteness, and some consist of jié with other verbs (Table 3 ).

In terms of semantic prosody, words co-occurring with jié are mostly positive or neutral, such as jié-guŏ, jié-hūn, jié-lùn, etc. Expressions like jié-hūn, jié-qīn are similar to jié-wèi-fū-qī or jiéwèifüfü or jié-lián-lĭ (to marry).

In ancient Chinese wedding ceremony, the hairs of both the bride and the bridegroom were tied together, meaning that they were never to be separated. Thus, the couple are tied and happy living together forever as jié-wèi-fī-qīor jiéwèi-fü-fü. As for jié-lián-lĭ, there is a beautiful love anecdote taking place between the Emperor of Tang Dynasty and one of the four beauties in Chinese history: Emperor Xuanzong and Lady Yang. And a famous poetic line sang highly of their union: Wish for a pair of lovebirds in the air, Willing to be twinned trunks on the ground. The marriage is conceptualized in terms of concrete objects, such as hair, trunk, etc. The expression di-jié is an official term for union between people, organizations, groups or larger entities like nations or national allies.

In terms of image schema of LINK,

(1) the link between people or organizations:

(this is similar to the image schema that two entities establish a link)

(2) the link with an end point:

(this is similar to the image schema of knotting a thread)

Then jiéwèifüqī or jiéwèifüfù or jiéliánlĭ (to marry) is more concrete and vivid than jiéhūn or jiéqinn, so more prototypical, too.

\subsection{2. jié (结), jì (系) and shù (束)}

The three Chinese words jié(结), $j i$ (系) and shì (束) all contain the meaning of knotting or tying. But the latter knotting verbs differ from jié (结) in range of application that $j i$ (系) usually occurs with objects like shoelace, necktie, belt, seatbelt, and the alike, while shù (束) usually occurs with objects like belt, hair, waist, or body. In the case of belt, both $j i$ (系) and shù (束) are possible collocators, but comparatively $j i$ (系) is relatively more common than shù (束).

Compared with $j i$ (系) and shù (束), jié(结) is more productive and active in practical use.

\subsection{3. jiě (解 Releasing or Unbinding)}

Chinese believe that everything knotted can be unknotted, and the unknotting philosophy is of greater significance. Then like jié (结), jiě (解) also play an active role in people's life, such as jiě-băo (解饱, satisfy one’s stomach), jiě-chán (解悗, satisfy an appetite for good food), jiě-chóu (解愁, to relieve from sorrow), 


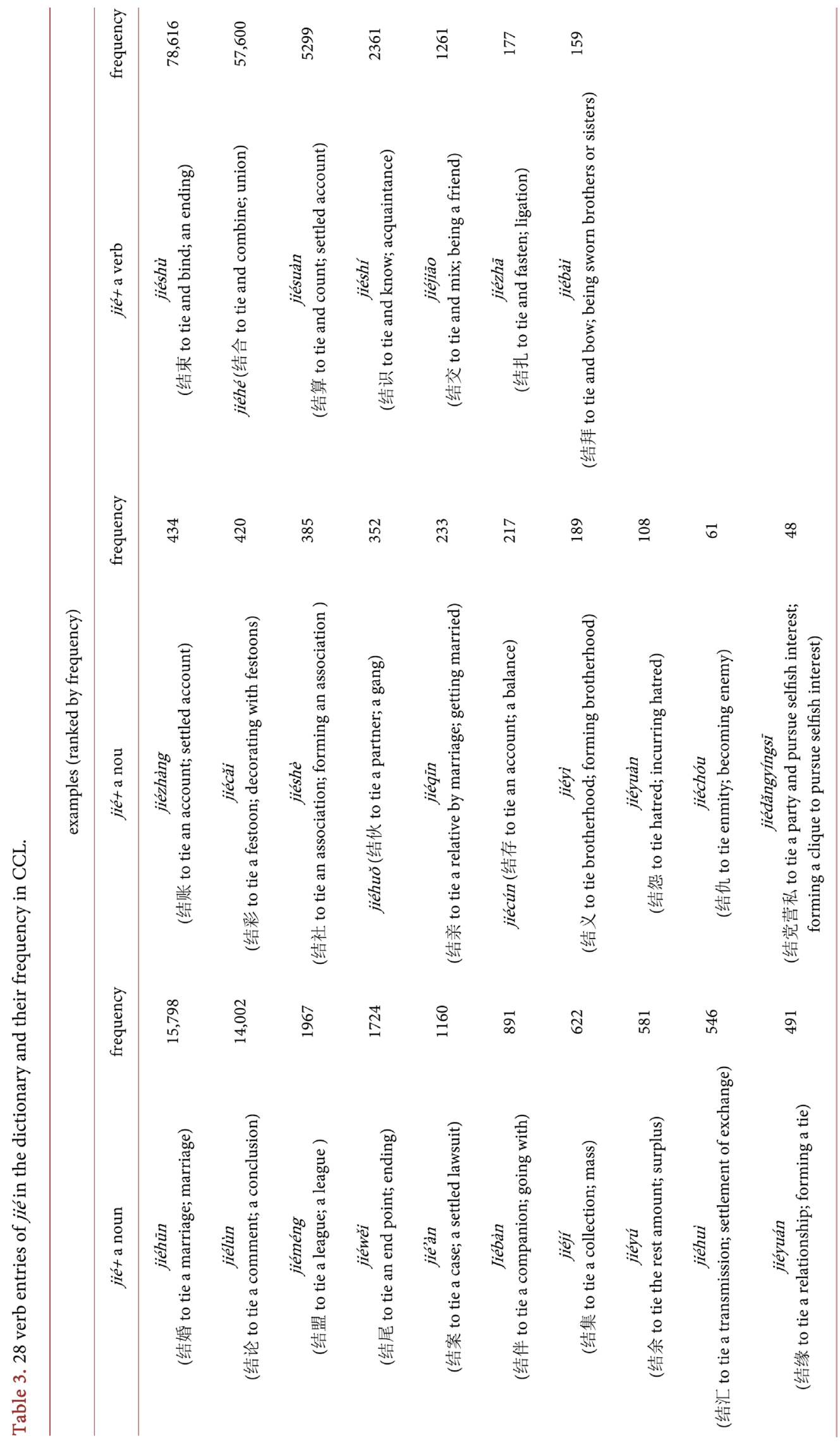


jiè-dòng (解冻, to unfreeze), jiě-dá (解答, to answer), jiě-shì (解释, toexplain), etc.

By looking into the Modern Chinese Dictionary there are altogether 49 verb entries of jiè. Among them, there are 34 jiě + noun and 15 jiě + verb.

jiě (解) usually refers to the opposite direction of jié (结), as illustrated in the following image schema:

(1) the link between one or two entities is unknotted:

(Q) $A$

(2) the link more than two entities is unknotted

(the dotted line indicates the unknotting

of the entangled links)

\subsubsection{Discussions}

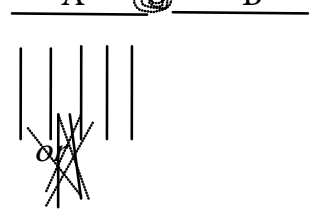

Comparing with the results of Table 3 and Table 4, jiě (解) is more commonly used in the practical language than jié (结). In the structure of $X+$ noun and $X+$ $v e r b$, both jiě (解) and jié (结) less occur with negative words. Expressions like jié-chóu (结仇 to tie enmity; becoming enemy) and jié-yuàn (结怨 to tie hatred; incurring hatred) appear at lower frequency than the other expressions. What's more, expressions like jié-shù (结束) and jiě-jué(解决) are particularly frequent in the practical use.

jié(结) and jiě (解) are a pair of act and counteract mostly referring to the link of one thread or between two threads. The subsets of jié (结) like jì (系) and shù (束) are opposite to jie (解). And in the case of two threads woven into a piece, $j i e ́$ (结) and jiě (解) can be substituted by biān (编 weave) or zhī (织 weave, knit) and chāi (拆 unweave, unknit).

\section{3. yīxiàn (一线 a Thread of) and yīsī (一丝 a Thread of)}

Both xiàn (线 thread) and $s \bar{l}$ (丝 thread) originally referred to the unit of textile fabric in the textile production. And now yī-xiàn (一线 a thread of) and $y \bar{i}-s \bar{i}$ (一 丝 a thread of ) are both used as quantifiers, meaning extremely small or subtle. (Modern Chinese Dictionary $6^{\text {th }}$ edition: 1528-1529) By accessing to CCL, both $y \bar{i}$-xiàn (一线 a thread of) and $y \bar{i}-s \bar{i}$ (一丝 a thread of) can co-occurs with expressions like $x \bar{i}$-wàng (希望 hope), shēng-jī (生机 life, vigor), shŭ-guāng (曙光 twilight), guāng-míng (光明 light).

But they also vary in their collocation preference. The most frequent expression $y \bar{i}-s \bar{i}$ (一丝 a thread of) usually co-occurs is xiào-róng (笑容 smile). What's more, $y \bar{i}-s \bar{i}$ (一丝 a thread of) have larger variety of expressions to co-occur with than yì-xiàn (一线 a thread of), like emotions (shì-luò 失落 sense of loss; qiàn-yi 歉意 apology, etc), feelings (nuăn-yi 暖意 warmth; hán-yi 寒意 coldness, etc). When yi-xiàn (一线 a thread of) co-occurs with prepositions like jiān (间 between) or zhï-jiān (之间 between), the expressions occur before the combination are only shēng-š̆ (生死 life and death). So when one's life is in danger, we can say “ming-xuán-yī-xiàn (命悬一线)". In other words, shēng-š̈-zhī-jiānzhí-yŏu-yí-xiàn-jù-lí (生死之间只有一线距离) means “There is only one line 


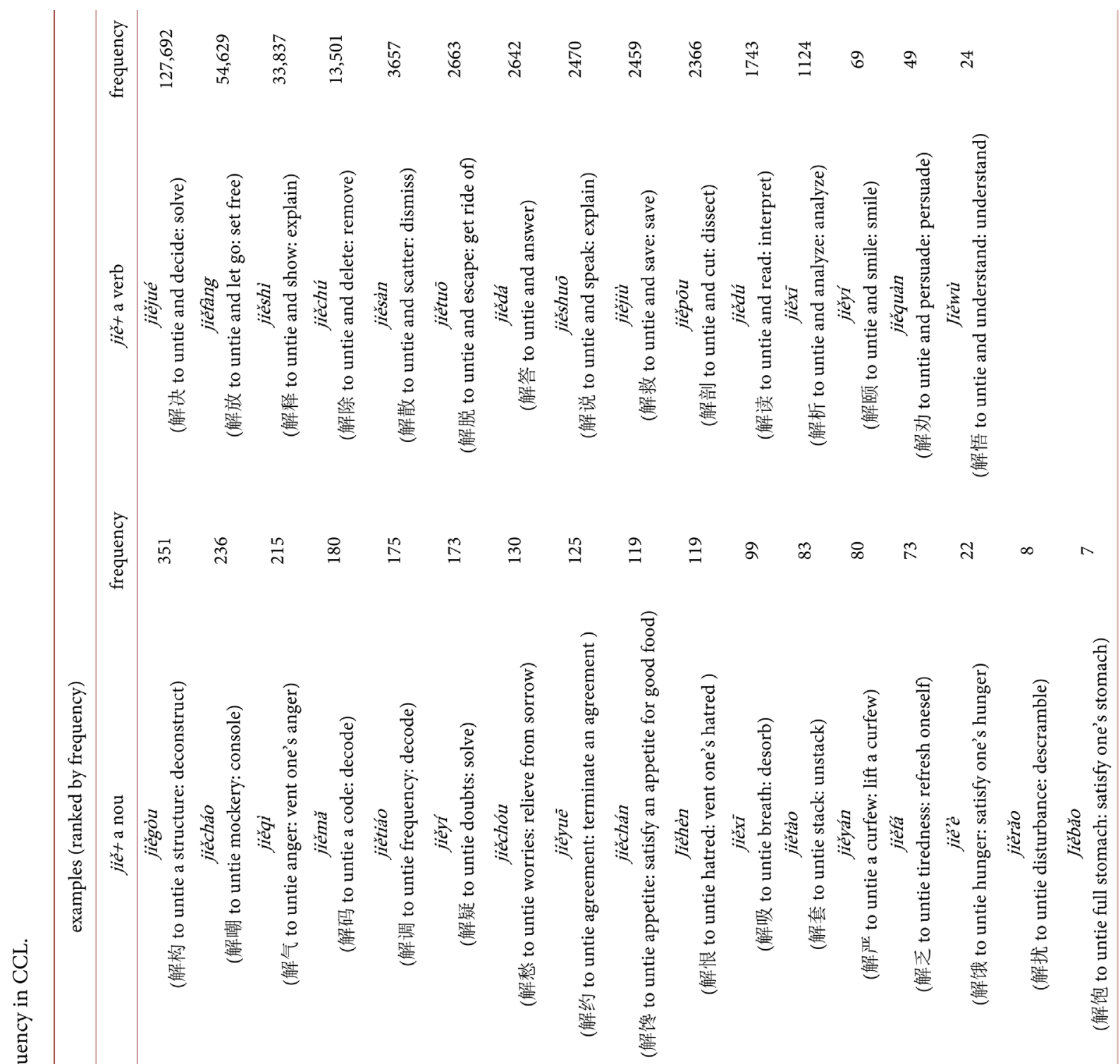

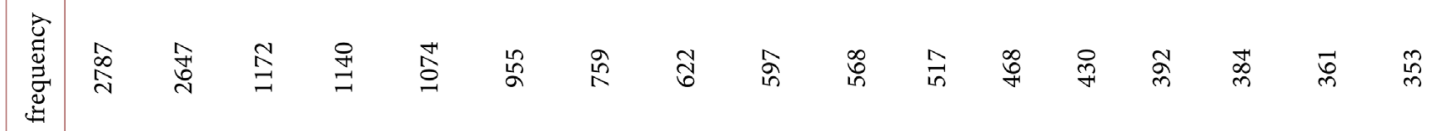


distance between life and death", metaphorically describing the fragile nature of life.

What's more, in practical use, $y \bar{i}-s \bar{i}$ (一丝 a thread of ) can be pluralized as $y \bar{i}-$ $s \bar{i}-s \bar{i}$ (一丝丝 threads of ), but yi-xiàn (一线 a thread of) cannot. For example, yī$s \bar{i}$ xiào-róng (一丝笑容 a thread of smile) indicates faint smile, while $y \bar{i}-s \bar{I}-s \bar{I}-$ xiào-róng (一丝丝笑容 threads of smile) connotes that though the smile is faint, it can appear on the face now and then, more likely to reveal the person's inner feelings.

\section{Conclusions}

By looking into the definitions in the Modern Chinese Dictionary and collecting data from Center for Chinese Corpus, it becomes clear that the conceptual metaphors involving thread or string prevail in Chinese and textile production related expressions have a salient experiential basis.

In the process of language development, the expressions extend metaphorically into the life domain, but vary in the degrees of prototypicality. The thread expressions conceptually link two domains, the domain of textile production and the life domain, and enrich the human's versatile ways of thinking.

\section{References}

[1] Palmer, G.B. and Sharifian, F. (2007) Applied Cultural Linguistics: An Emerging Paradigm. In: Palmer, G.B. and Sharifian, F., Eds., Applied Cultural Linguistics, John Benjamins Publishing Company, Amsterdam/Philadelphia, 1-14. https://doi.org/10.1075/celcr.7.02pal

[2] Sharifian, F. (2007) L1 Cultural Conceptualisations in L2 Learning: The Case of Persian-Speaking Learners of English. In: Palmer, G.B. and Sharifian, F., Eds., Applied Cultural Linguistics, John Benjamins Publishing Company, Amsterdam/ Philadelphia, 33-51. https://doi.org/10.1075/celcr.7.04sha

[3] Yu, N. (2003) Metaphor, Body, and Culture: The Chinese Understanding of Gallbladder and Courage. Metaphor and Symbol, 18, 13-31. https://doi.org/10.1207/S15327868MS1801_2

[4] Yu, N. (2008) The Relationship between Metaphor, Body and Culture. In: Frank, R.M., Dirven, R., Zieme, T. and Bernárdez, E., Eds., Body, Language and Mind Volume 2: Sociocultural Situatedness, Walter de Gruyter GmbH \& Co. KG, Berlin, 387-407.

[5] Lakoff, G. and Johnson, M. (1980) Metaphors We Live By. University of Chicago Press, Chicago.

[6] Center for Chinese Linguistic. http://ccl.pku.edu.cn:8080/ccl_corpus/

[7] (2012) Modern Chinese Dictionary. 6th Edition, The Commercial Press, Shanghai.

[8] Chinese Characters. Retrieved on July 31, 2017. http://en.wikipedia.org/wiki/Chinese_characters

[9] Gao, Q. (2015) On Creative Fashion Design on the Basis of Traditional Textile Craft. Fashion Guide, No. 4, 87-91.

[10] Longman Dictionary of Contemporary English. http://www.ldoceonline.com/dictionary/weave 
Submit or recommend next manuscript to OALib Journal and we will provide best service for you:

- Publication frequency: Monthly

- 9 subject areas of science, technology and medicine

- Fair and rigorous peer-review system

- Fast publication process

- Article promotion in various social networking sites (LinkedIn, Facebook, Twitter, etc.)

- Maximum dissemination of your research work

Submit Your Paper Online: Click Here to Submit

Or Contact service@oalib.com 